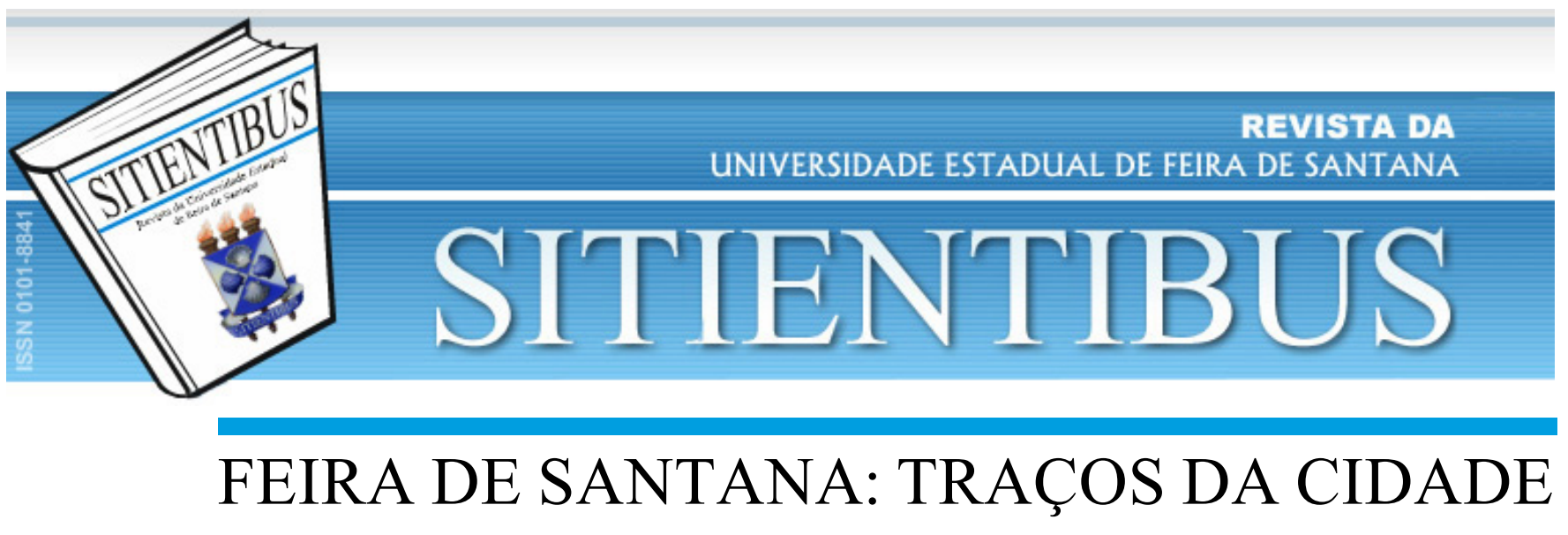

ARTIGO

\title{
REGIÃO METROPOLITANA DE FEIRA DE SANTANA: DA PROPOSTA ÀS CARACTERÍSTICAS ATUAIS
}

\section{THE METROPOLITAN REGION OF FEIRA DE SANTANA: FROM PROPOSAL TO CURRENT CHARACTERISTICS}

\section{EDSON DA SILVA SANTOS}

Graduado em Geografia/UEFS. E-mail: edsonsporte@hotmail.com

\section{RESUMO}

As Regiões Metropolitanas (RMs) são recortes espaciais formados pela junção de dois ou mais municípios, instituídas por meio de lei, com vistas ao planejamento e realização de funções públicas de interesses comuns. A Região Metropolitana de Feira de Santana (RMFS) foi instituída e colocada como uma forma de alavancar o desenvolvimento econômico, sustentável e equilibrado dos municípios limítrofes a ela. Ante essa proposta, elaborou-se este artigo, que tem como cerne fazer uma caracterização da RMFS, no que tange aos aspectos históricos e principalmente atuais, referentes à centralidade da cidade polo e às dinâmicas populacional e econômica, para que os fundamentos de sua institucionalização possam ser verificados. A metodologia empregada fez uso, sobretudo, de pesquisa bibliográfica dos principais conceitos e documental. Como resultado pontuase que a centralidade do núcleo se amplia, a RMFS não foi regulamentada e somente Feira de Santana, Conceição do Jacuípe e Riachão do Jacuípe apresentam aspectos populacionais e econômicos com caráter metropolitano.

Palavras-chave: Feira de Santana. Região Metropolitana. Institucionalização. Aspectos Socioeconômicos.

\begin{abstract}
The Metropolitan Regions (RMs) are space cuts formed by the union of two or more municipalities, established by law, with a view to planning and carrying out public functions of common interests. The Metropolitan Region of Feira de Santana (RMFS) was instituted and placed as a way to leverage the sustainable and balanced economic development of the municipalities bordering it. Before this proposal, this article was elaborated with the main purpose of making a characterization of the RMFS, in what concerns the historical and mainly current aspects, referring to the centrality of the polo city and to the population and economic dynamics, so that the foundations of their institutionalization can be verified. The used methodology was mainly bibliographical research of the main concepts and documentary. As a result, it is noted that the centrality of the nucleus expands, the RMFS has not been regulated and only Feira de Santana, Conceição do Jacuípe and Riachão do Jacuípe have metropolitan population and economic aspects.
\end{abstract}

Keywords: Feira de Santana. Metropolitan Region. Institutionalization. Socioeconomic Aspects. 


\section{INTRODUÇÃO}

Regiões Metropolitanas (RMs) são resultantes do processo da união de dois municípios, cuja forma de delimitação, reconhecimento e institucionalização do recorte socioespacial ocorre por meio de lei, segundo critérios técnicos, conceituais e metodológicos, com o objetivo da gestão regional, crescimento ordenado, planejamento integrado, diminuição das desigualdades socioeconômicas, dentre outros, assim como envolve interesses políticos.

No Brasil, sob o ponto de vista do discurso político, tais instituições predizem benefícios para os municípios componentes das mesmas, como acesso de forma diferenciada a investimentos públicos e a programas e projetos do Governo Federal. Ademais, propõem unificação das tarifas telefônicas, com custo local que também vale para passagens de ônibus intermunicipal; integração da área educacional e da saúde; bem como gestão de problemas comuns, como violência, tráfico de drogas, entre outros. Algo que tem contribuído para a crescente institucionalização dessas regiões em todo país.

A Região Metropolitana de Feira de Santana (RMFS) não foi diferente. Instituída em seis de julho de 2011, por Lei Complementar estadual no 35 (BAHIA, 2011), precedeuse por discursos políticos que a defendiam como forma de trazer benefícios aos municípios a ela pertencentes. Contudo, após sete anos de ter sido sancionada pelo então governador do Estado, Jaques Wagner (PT), a RMFS, na prática, não fora concretizada; por exemplo, o conselho de desenvolvimento metropolitano, responsável por gerir tal região, ainda não foi criado.

Dada a sua não efetivação, desenvolveu-se este artigo, com objetivo trazer uma caracterização da RMFS, no que tange aspectos históricos e principalmente atuais, referentes à centralidade da cidade polo, assim como as dinâmicas populacional e econômica dessa região, para que possam ser verificados os fundamentos de sua institucionalização. Para tanto, fez-se uso de pesquisa bibliográfica e de documentos oficiais e fontes estatísticas.

O texto está organizado em três partes: primeiramente, reflete-se sobre os conceitos de RM e o viés legal da institucionalização de RMs no Brasil. Posteriormente, realiza-se um apanhado histórico do processo de institucionalização da RMFS, sua composição e condição atual. Por final, caracteriza-se as dinâmicas populacional e econômica da RMFS e Área de Expansão, em que destaca-se a centralidade de Feira de Santana em relação a sua região de influência e enquanto polo, bem como são pontuadas as contradições existentes.

\section{REGIÃO METROPOLITANA: PROCESSO SOCIOESPACIAL, INSTITUCIONAL E IMPLICAÇÕES}

Do ponto de vista socioespacial, as RMs resultam do processo de metropolização. Contudo, há dois tipos de metropolização: a socioespacial e a institucional (FIRKOWSKI, MOURA, 2001). Tais processos são indissociáveis, pois as institucionalizações dessas regiões advêm das necessidades oriundas da metropolização, tida enquanto processo decorrente do crescimento urbano, que extrapola os limites políticos administrativos de um município e agrega áreas urbanas de outros, por meio da conurbação. Isso não significa dizer que tais espaços em processo de metropolização não fossem integrados por meio de redes que modificam relações espaços temporais (PEREIRA, 2015).

No Brasil, a metropolização socioespacial, num primeiro momento, esteve atrelada à intensificação do êxodo rural para área de produção industrial, situada principalmente nas Regiões Sul e Sudeste do país, cujo impulso deu-se também em razão da modernização do campo, que expulsou trabalhadores e pequenos proprietários de terra para a cidade, teoricamente, em busca de melhores condições de vida, em especial nos locais onde houve uma industrialização mais ampla. Contudo, contribuiu para que as cidades se apresentassem "inchadas" e com alta percentagem de população marginalizada e subempregada (GALVÃO, et al., 1996).

No contexto atual, o processo de metropolização, não desconectado do atrativo industrial, encontra-se vinculado à globalização. Entretanto, em ambos os casos prediz a existência de uma metrópole que, segundo Robira (2005), compreende uma grande cidade que coloniza, subjuga, impõe e dispõe seus interesses em relação ao espaço que a ela depende, seja uma área ou RM. Desse modo, assim como as metrópoles, as RMs resultam da metropolização. Contudo, sob o ponto de vista teórico-metodológico e conceitual, para o Observatório das Metrópoles (2012), uma RM prediz a existência de uma metrópole que apresente, para além de seu polo, ou seja, da sua zona de influência, dinâmicas de integração altíssimas, sejam na escala regional e/ou nacional.

Tal zona de influência pode e dever ser usada para delimitar a RM, composta por uma metrópole, juntamente com um ou mais municípios que formam uma área densamente urbanizada e uma imensa comunidade socioeconômica. Nesse sentido, para Robira (2005, p. 13), a RM é um "[...] território mais ou menos urbanizado que fica em torno de uma grande cidade e depende dela". Ou seja, em torno de uma metrópole o território pode ser totalmente urbanizado, com presença de conurbações entre um ou mais municípios. Isso porque pode haver na metrópole e/ou na $\mathrm{RM}$ áreas rurais e/ou acidentes geográficos naturais, que dificultam a conexão física do espaço urbano.

No âmbito legal, a primeira constatação e institucionalização de uma RM, segundo Freitas (2009), ocorreu na Inglaterra no século XIX, cujo processo de metropolização desencadeou-se a partir da Primeira Revolução Industrial, período em que a atividade fabril promoveu o aumento da urbanização por meio do fluxo migratório das pessoas do campo para a cidade. Em resposta a esse processo, o governo inglês instituiu a RM em torno de Londres, ideia seguida por administradores de Tóquio, Cidade do México, Buenos Aires, Toronto, Barcelona e, hoje, muitas outras. 
No Brasil, as primeiras RMs foram criadas em torno das grandes capitais durante as décadas de 1960/1970, no período de vigência do Regime Militar, em resposta à urbanização acelerada que ocorreu no contexto, sobretudo devido aos altos fluxos migratórios, cujo sentido campo-cidade convergia para as áreas dos primeiros impulsos da atividade industrial, ou seja, para São Paulo e Rio de Janeiro. Dessa forma, surgiram em um governo autoritário, centralizador e tecnocrático, "Tidas na visão do regime militar, como regiões que desempenhavam papel-chave na consolidação do processo de crescimento e não propriamente de desenvolvimento do País" (SOMEKH, 2010, p. 10).

O estabelecimento de RMs, no Brasil, foi iniciado pelo Estado do Rio Grande do Sul, que, em 1968, estabeleceu a Região Metropolitana de Porto Alegre (RMPA). Ao reconhecêla, o Governo Federal, por meio da Lei Complementar № 14, de 8 de julho de 1973, instituiu as oito primeiras: São Paulo, Belo Horizonte, Porto Alegre, Recife, Salvador, Curitiba, Belém e Fortaleza (BRASIL, 1973). Em 1974, após a extinção do Estado da Guanabara e sua fusão ao do Rio de Janeiro, fora estabelecida a Região Metropolitana do Rio de Janeiro (RMRJ), por meio da LC no 20 de 1ㅇ de julho de 1974 (BRASIL, 1974). Ação que totalizou nove RMs institucionalizadas.

A instituição dessas regiões teve como objetivo consolidar planos e programas. Isso porque, segundo Matos (1982), o Governo Federal a elas vinculava obrigatoriamente parcela de fundos federais, como o Fundo de Participação dos Estados (FPE) e do Fundo de Participação dos Municípios (FPM), assim como criou órgãos e outros fundos para apoio, coordenação e financiamento de programas com vistas ao seu desenvolvimento. Nesse período, foram criados três planos nacionais, a saber: I Plano Nacional de Desenvolvimento (PND), para o período de 1972 a 1974; II Plano Nacional de Desenvolvimento (PND), para o período de 1975 a 1979); III Plano Nacional de Desenvolvimento (PND), para o período de 1980 a 1985 (BRASIL, 1971, 1974, 1980).

Com a redemocratização, a promulgação da Constituição de 1988 , no art. $25, \S 3 \%$, transferiu a competência de instituir as RMs da União para as Unidades da Federação (UF), que, por meio de lei complementar, tornaram-se capazes de instituí-las, igualmente as aglomerações urbanas e as microrregiões, assim como acrescentar ou retirar municípios às pré-existentes ou destituí-las para fins de planejamento integrado e execução de funções públicas de interesse comum (BRASIL, 1988). Contudo, não as tornaram entes federados autônomos, com personalidade jurídica e capacidade de autogestão (MAGALHÃES, 2008), status dado aos estados, Distrito Federal e municípios.

Sem paramentos nacionais ou regionais as UF estabelecem seus próprios critérios referenciais, de acordo com seus interesses, que variam de estado para estado e de região para região. Tal ausência resultou em termos qualitativos e quantitativos numa "explosão" de unidades regionais assaz heterogêneas, quase sempre urbanizadas, mas que, apesar de serem regiões, não são necessariamente metropolitanas.
Assim como permitiu a destituição de muitas que não possuíam os critérios mínimos para se constituírem enquanto tal (FIRKOWSKI, 2011).

Ao analisar a rede urbana brasileira e classificar sua hierarquia, segundo as regiões de influências das cidades nas Unidades da Federação UFs, com base no Regiões de Influências das Cidades (REGIC) de 2007, o Instituído Brasileiro de Geografia e Estatística (IBGE) pondera que o Brasil possui apenas 12 RM (IBGE, 2008). Todavia, até 26 de março de 2018, segundo o Fórum Nacional de Entidades Metropolitanas (FNEM), possuía 74 regiões metropolitanas, três Regiões Integradas de Desenvolvimento Econômico (RIDE) e cinco Aglomerações Urbanas (AUs), o que totaliza 81 unidades territoriais institucionalizadas. Ou seja, excetuandose as nove RMs instituídas pela União até 1988, o Brasil possuía 65 RMs criadas por leis complementares estaduais (OBSERVATÓRIO DA METRÓPOLE, 2012).

Quanto ao esperado Estatuto da Metrópole (EM), que, dentre outros aspectos, estabeleceu os critérios técnicos conceituais necessários para se instituir ou destituir RM e AU no país, esse foi aprovado por meio de LC № 13.089, de 12 de janeiro de 2015 (BRASIL, 2015). Contudo,não conseguiu barrar a instituição de RMs que continua a acontecer, assim como não ponderou sobre o que será feito das regiõeslegalmente instituídas, principalmente aquelas que não possuem caráter metropolitano.

Face ao exposto e do ponto de vista legal, uma RM é um recorte espacial formado pela junção de um ou mais municípios, cuja delimitação e reconhecimento, no Brasil, após a Constituição de 1988, ocorre por meio de LC estadual, segundo critérios técnicos adotados por cada unidade da federação, assim como envolve interesses políticos, com objetivo de desenvolvimento regional ao integrar a organização, o planejamento e a gestão de interesse comum dos municípios (MOREIRA JR., 2013).

\section{INSTITUCIONALIZAÇÃO DA REGIÃO METROPOLITANA DE FEIRA DE SANTANA: COMPOSIÇÃO E CONDIÇÃO ATUAL}

Ante ao exposto, tem-se, face o processo de institucionalização de RMs, como competência das UF, com o objetivo de descentralização econômica e fomento à redução das desigualdades socioeconômicas, previstos na constituição de 1988, que como Projeto de Lei Complementar (PLC) no 35 de 1994, de autoria do então Deputado Estadual Colbert Martins da Silva Filho, fez-se a primeira tentativa de instituir a RMFS, na Assembleia Legislativa do Estado da Bahia (ALBA), no dia 29 de julho de 1994. O referido projeto pleiteava a institucionalização da RMFS, formada primeiramente por 15 municípios, com a possibilidade de ampliação desse número, conforme versa o artigo 20․ Segundo Silva (2014), o PLC de no 35/94 foi rejeitado sob a justificativa da ausência de suporte técnico capaz de embasar a instituição de uma nova RM e foi arquivado, para não ter a legitimidade comprometida. A partir de então, a proposta foi (re)aberta e arquivada por diversas vezes. 
Contudo, em 2009, o então Deputado Colbert Martins Filho retomou a discussão sobre a criação da RMFS.

A retomada da proposta de criação da RMFS, em oito de abril de 2011, ocorreu na Câmara Municipal de Feira de Santana, em uma sessão especial, sob o requerimento $n^{\circ}$ 17/2011. Em 14 de junho de 2011 foi encaminhada a ALBA a proposição MSG/4.677/2011, com o anexo do PLC que pleiteava instituí-la, em razão do destaque que a cidade polo e os municípios circundantes apresentaram, nos últimos anos, no setor comercial, serviço e industrial, com o intuito de promover o desenvolvimento socioeconômico integrado, equilibrado e sustentável, assim como a redução das desigualdades no âmbito dessa região (BAHIA, 2011a).

Em 16 de junho de 2011, o PLC no 106 foi votado e aprovado, com maioria de votos, na primeira sessão ordinária itinerante da ALBA, realizada no interior da Bahia, sediada em Feira de Santana, com um voto contra. Assim foi instituída a RMFS, inicialmente composta por seis municípios: Feira de Santana, Amélia Rodrigues, Conceição da Feira, Conceição do Jacuípe, São Gonçalo dos Campos e Tanquinho; e por uma Área de Expansão Metropolitana, com dez municípios: Anguera, Antônio Cardoso, Candeal, Coração de Maria, Ipecaetá,

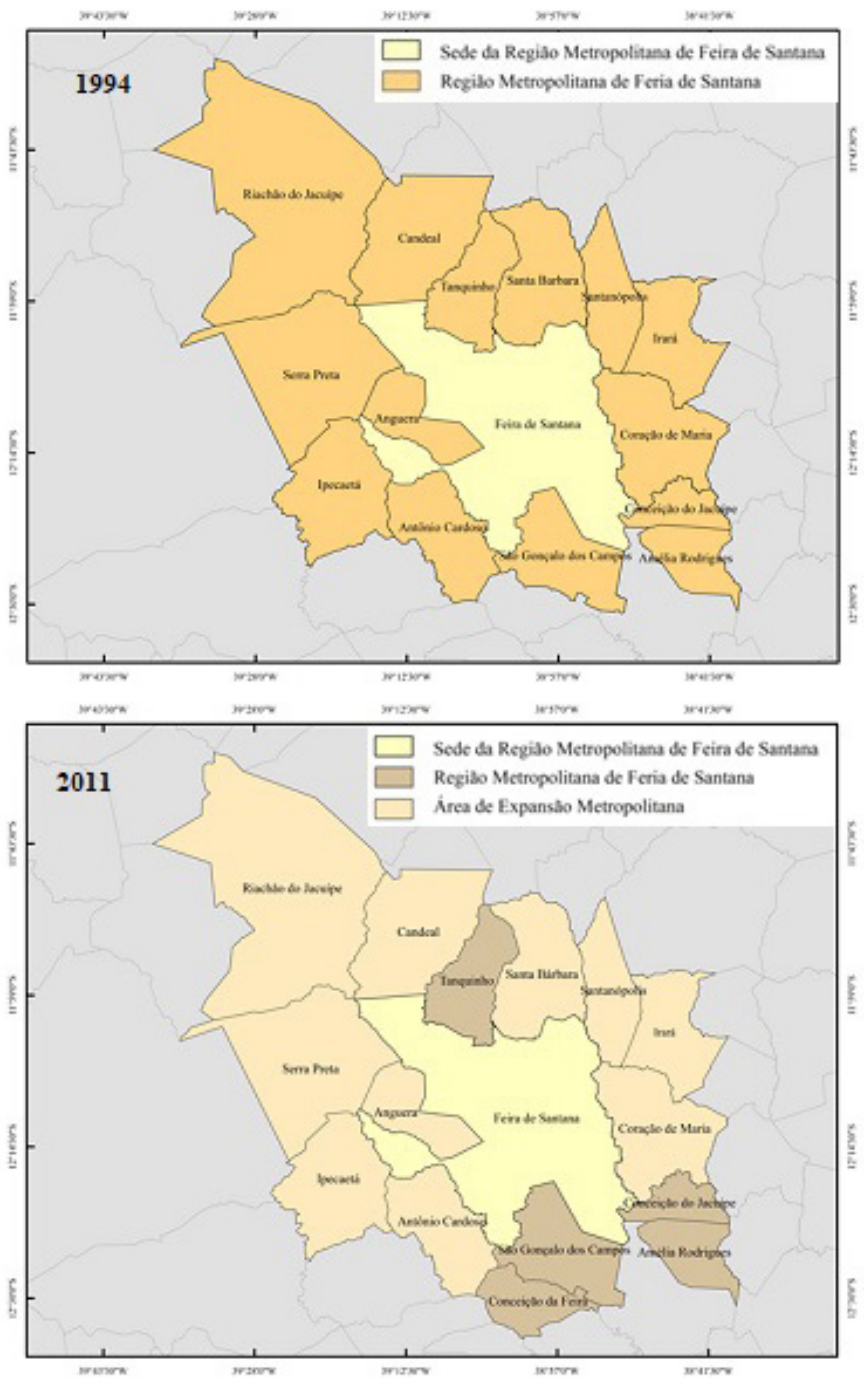

Irará, Santa Bárbara, Santanópolis, Serra Preta e Riachão do Jacuípe (BAHIA, 2011a).

O projeto de lei foi enviado pelo então Governado Jaques Wagner, que para ser aprovado deveria recusar toda e qualquer emenda parlamentar (ALBA, 2011). Contudo, para fazer parte da região os municípios deveriam apresentar os seguintes critérios, posteriormente divulgados na mídia, a saber: taxa de urbanização de no mínimo 50\%; ser limítrofes; ter fluxos de relação; e, no mínimo, possuir $4 \%$ do Produto Interno Bruto (PIB) estadual. Ao ser aprovado, o PLC no 106 de 2011 passou a ser denominado de LC no 35 de 06 de julho de 2011, publicada no dia sete do mesmo mês e ano (BAHIA, 2011b).

Para Freitas (2014, p. 304), a RMFS "nasce com a consolidação da macrocefalia e extrema centralização econômica. Tais aspetos impõem o desafio para a gestão do espaço que se apresenta diferenciado e profundamente hierarquizado".

Sobre os benefícios financeiros de se fazer parte de uma RM no contexto atual, a instituição da RMFS ocorreu num momento em que o governo federal retomou discussões, propostas e destinação de projetos e linhas de investimentos a espaços metropolitanos, como ocorreu com as instituídas em 1973 e 1974. Nessa retomada, destaque para três Programas:
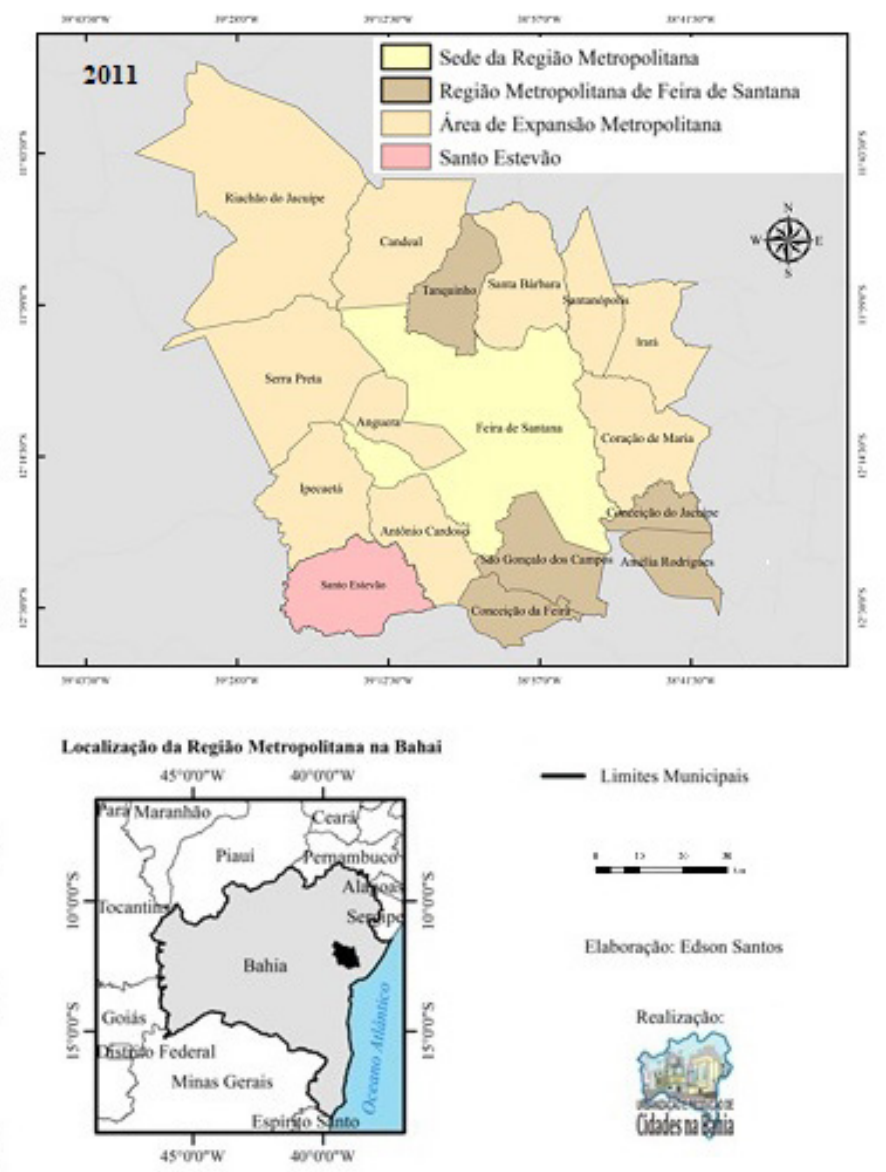
Fonte: BAHIA (2011, 2018): Obsenatório das Metrópoles (2012) Coordenadas Geogrificas: Lat e Long
de Referénsia das Coondenadas: SIRGAS 2000

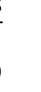
. . 

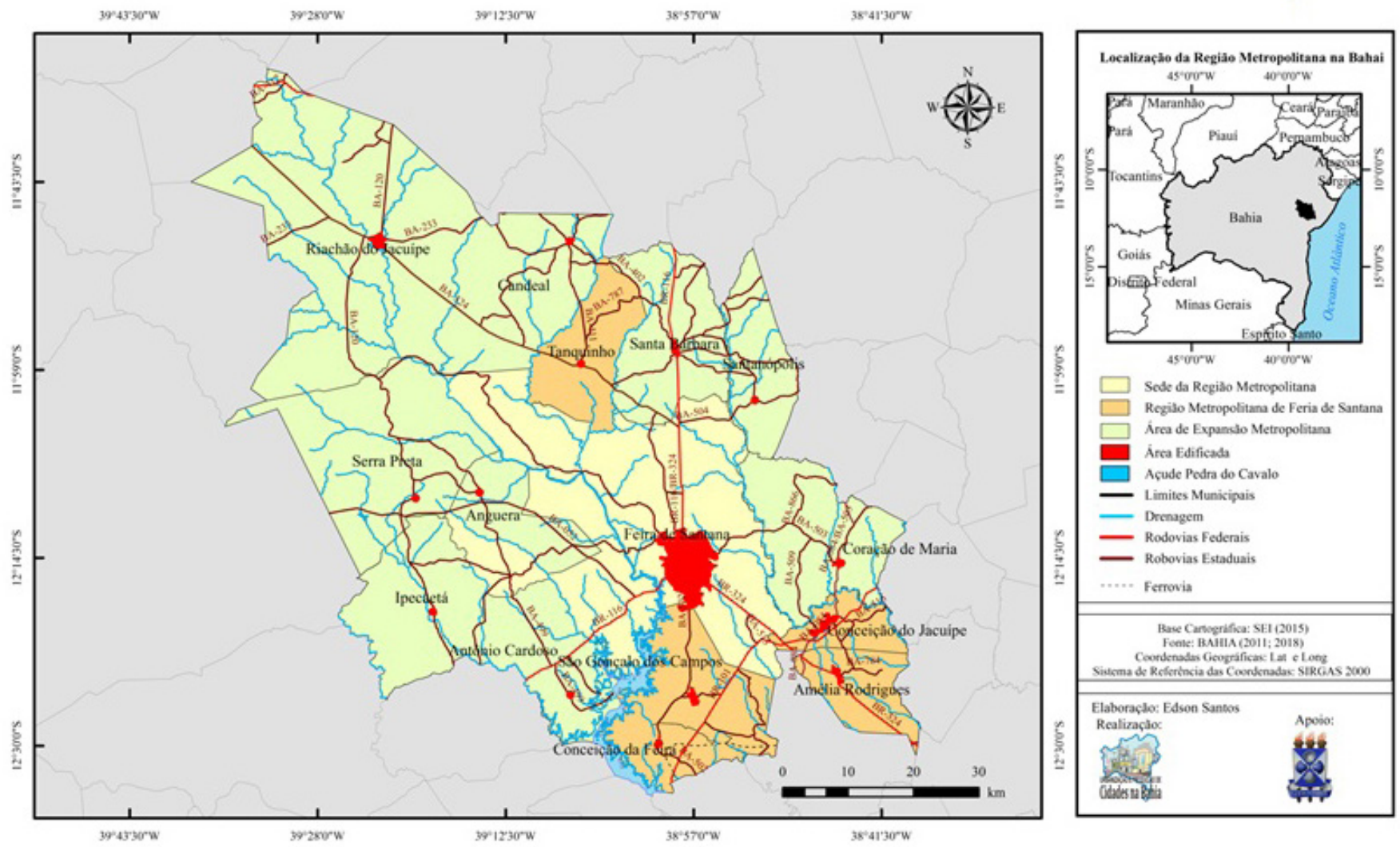

Mapa 2- Região Metropolitana de Feira de Santana e Área de Expansão atual, 2018.

Nacional de Segurança Pública com Cidadania (PRONASCl), Minha Casa, Minha Vida (PMCMV), Aceleração do Crescimento I e II (PAC I e II), (BRASIL, 2007, 2018).

Pautado na possibilidade de ampliação da RMFS, seja por meio da inclusão de municípios pertencentes à Área de Expansão ou por outros motivos, algo possível e assegurado no Brasil por leis federais e estaduais, ao permitirem a exclusão e inclusão de municípios oriundos de fusão ou desmembramento dos já pertencentes a uma RM, foi que Santo Estevão, município não pertencente à Área de Expansão Metropolitana de Feira de Santana e tampouco contiguo à RMFS, tentou fazer parte dela por meio do PLC № 109/2011. Para tanto, ancorou-se nos dados da taxa de urbanização que são da ordem de $75.8 \%$, algo que atende a um dos critérios exigidos para inserção (Mapa 1). Contudo, teve o projeto de Lei arquivado em 07 de abril de 2016 (BAHIA, 2011c).

Embora haja municípios que queiram fazer parte de RMs, seja por questões de status ou devido à possibilidade de acessar investimentos do governo federal e estadual, Irará, que era pertencente à Área de Expansão Metropolitana da RMFS, deixou de fazer parte, por meio da publicação da LC no 45, de 4 de julho de 2018 (BAHIA, 2018a). Após sua saída, a Área de Expansão Metropolitana passou a ser composta por nove municípios, a RMFS continuou com seis municípios e apresentam a configuração representada no Mapa 2.

Todavia, após sete anos de instituída, a RMFS encontra-se sem efetivação, isso porque o Conselho de Desenvolvimento Metropolitano, órgão que deveria gerir essa região, não foi criado, pois falta o Governador do Estado sancionar o decreto que regulamenta a região. Contudo, a busca pela efetivação se faz presente no Plano Diretor de Desenvolvimento Urbano e Territorial do Município de Feira de Santana (PDDU), de 2018. Dentre as providências, propõe formas de articulação por meio da criação de um Fórum dos Municípios da Região Metropolitana de Feira de Santana, com o objetivo de pôr em prática os Conselhos metropolitanos, por meio da participação popular (FEIRA DE SANTANA, 2018a).

Advém também de Feira de Santana a iniciativa de políticos que criaram e aprovaram em 2018, na Câmara de Vereadores, o Projeto de Resolução de no 709/2018, que instituiu a Frente Parlamentar Mista de Desenvolvimento da Região Metropolitana de Feira de Santana, com vistas ao desenvolvimento dessa região, por meio da Resolução № 516/2018 (FEIRA DE SANTANA, 2018b).

\section{CARACTERIZAÇÃO DA REGIÃO METROPOLITANA DE FEIRA DE SANTANA E ÁREA DE EXPANSÃO}

Com a instituição da RMFS, o Estado da Bahia passou a ter três aglomerados urbanos legalmente instituídos: a Região Metropolitana de Salvador (RMS), estabelecida por LC Federal em 1973; a RIDE do Polo Petrolina/PE e Juazeiro/ BA, instituída por LC no 113, de 2001 e regulamentada pelo Decreto no 4.366, de 2002 (BRASIL, 2001, 2002); e a RMFS, instituída por LC estadual em 2011. 
As RMs da Bahia foram estabelecidas em torno dos principais centros urbanos do estado, Salvador e Feira de Santana, que, de acordo com o IPEA, são respectivamente metrópole e polo estadual, principais níveis hierárquicos dos centros urbanos numa escala de sete níveis: metrópole, polo estadual, polo regional, polo sub-regional, polo local, centro local e núcleo (IPEA, 2013, p. 18). Para o IBGE (2008), a Região Metropolitana de Salvador (RMS) mantem o status de metrópole e Feira de Santana é uma Capital Regional de nível $B$, compreendida como "área de influência de âmbito regional, sendo referidas como destino, para um conjunto de atividades, por grande número de municípios" (IBGE, 2008, n.p).

$\mathrm{Em}$ estudo recente, o IBGE estabeleceu uma nova regionalização para o Brasil, em substituição as microrregiões e mesorregiões geografias de 1990. Nessa, Feira de Santana passou a ser denominada Região Geográfica Imediata, composta por 33 municípios, e Região Geográfica Intermediária, compreendida por 83 municípios (IBGE, 2017). Ademais, a cidade também possui conexões com São Paulo, grande metrópole nacional, Belo horizonte e Brasília, metrópoles nacionais, e logicamente com Salvador, metrópole regional (IBGE, 2008). A centralidade dá-se em razão da posição estratégica que Feira de Santana apresenta ao situar-se em importante entroncamento rodoviário, por onde passam cinco rodovias estaduais, tais como as BAs 052, 084, 502, 503 e 504 e três federais: BRs 101, 116, 324.

Por via aérea, a RMFS dispõe do Aeroporto Governador João Durval Carneiro, situado em Feira de Santana, inaugurado em 1985, todavia, reinaugurado com voos comerciais em 2014.
Atualmente, realiza um voo por semana, com destino ao Aeroporto Internacional Tancredo Neves em Confins, Minas Gerais. Porém, há previsão de voos diários, em caráter experimental, com destino a Campinas-SP, entre 20 de dezembro de 2018 e 03 de fevereiro de 2019; e semanal, a partir de agosto de 2019, para Recife-PE, (TRINDADE, 2018).

No contexto atual, a centralidade de Feira de Santana vincula-se ao fato de ser um grande centro distribuidor de bens e serviços nos setores comercial, industrial, educacional, saúde, esporte e lazer, além de assistência técnica profissional e especializada. São atividades responsáveis por promover o fluxo pendular dessa e/ou para essa cidade, sobretudo, intermunicipal, para trabalhar e/ou estudar em outro município que não o de residência, em buscar de satisfazer, por exemplo, demandas laborais ou enquanto cidade de passagem.

No comércio, Feira de Santana tornou-se a cidade de grandes empreendimentos atacadistas e varejistas, cujas lojas localizam-se em pontos estratégicos, tais como o Atacadão I e II, o Assaí Atacadista, o Atacadão São Roque, entre outros. Já em fase de construção, encontram-se o Atakadão Atakarejo e o Maskate Atacado. Além desses, é possível encontrar grandes supermercados da Rede Cencosud, como o Mercantil Rodrigues e o GBarbosa. Nos serviços, é centralidade de sua região por sediar importantes órgãos públicos estaduais e federais, assim como instituições educacionais, de saúde, transportes e serviços bancários. Algo que a coloca, após Salvador, como aquela com maior presença de atividades e serviços considerados raros e de maior complexidade, numa escala definida entre máxima, alta, média, baixa e mínima,
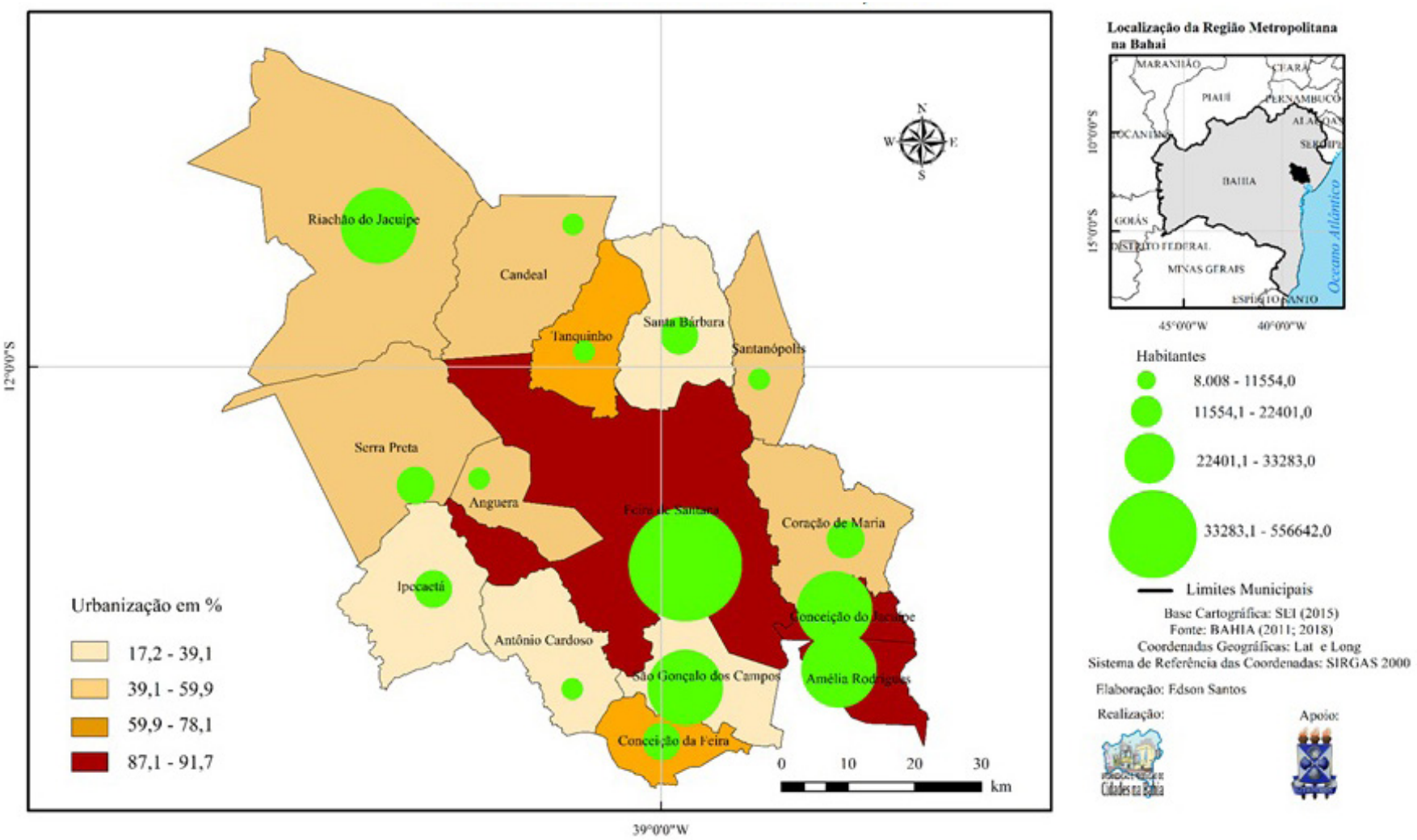

Mapa 3- Taxa de urbanização e população total da Região Metropolitana de Feira de Santana e Área de Expansão, 2010 
que podem ser comércio/serviço, bancos, saúde, ensino superior e gestão. Enquanto Salvador apresenta concentração máxima em todos, Feira de Santana possui máxima apenas na gestão, referente às instituições/órgãos. Os demais setores apresentam concentração alta (IPEA 2013).

Em termos territóriais, a RMFS, conforme Tabela 1, possui uma área de $2312,472 \mathrm{~km}^{2}$, cuja densidade demográfica é de 291,3 (hab./ $/ \mathrm{km}^{2}$ ). Feira de Santana desponta tanto em termos territoriais, ao dispor de $1.337,993 \mathrm{Km}^{2}$, quanto em densidade demográfica, ao apresentar $416,03 \mathrm{hab} . / \mathrm{km}^{2}$. No tocante à Área de Expansão, a área total é de $3.937,828 \mathrm{Km}^{2}$, com densidade demográfica de 13,49 hab./ $\mathrm{km}^{2}$. Observase superioridade de Riachão do Jacuípe no tamanho do território, ao apresentar 1190,196 Km², ainda que a maior densidade esteja em Coração de Maria, com 64,34 hab./km².

No que diz respeito à urbanização da RMFS, tem-se que Feira de Santana e Conceição do Jacuípe são os municípios que mais se destacam. Enquanto o primeiro apresenta 510.635 pessoas a residir em espaços urbanos, os demais não passam de 24 mil, conforme Tabelas 1 e 2. Na Área de Expansão, o destaque é dado a Riachão do Jacuípe. Diante disso, percebese que o maior peso demográfico se encontra na cidade polo, por concentrar considerável população total e urbana, e altas densidade demográfica e taxa de urbanização (Mapa 3). Quase todos os demais, apesar de alguns terem população urbana superior a rural, são notadamente rurais e parece não ter sentido considerá-los metropolitanos.
A estimativa populacional da RMFS para 2018, conforme dados do IBGE, foi de 713.486 habitantes. Em relação a 2010, tal crescimento poderá ter contribuição significativa de Feira de Santana, cuja perspectiva de incremento é de 53.271 habitantes, e São Gonçalo dos Campos, com 3.856. Dois municípios tendem a diminuir população, a saber: Tanquinho e Conceição do Jacuípe, em 99 e 29.131 habitantes, respectivamente. Para a Área de Expansão, poderá haver incremento de 39.057 habitantes, cuja maior contribuição é de Coração de Maria, estimada em 5.318; e de Santa Barbara, com 1.630. Três municípios apresentam tendência a diminuição, destaques para Ipecaetá, 706 habitantes, e Candeal, 557.

Ao consultar no IBGE e analisar a evolução da população rural entre 1940 a 2010, constatou-se, conforme Tabela 2, que a RMFS apresentou decréscimo, sobretudo a partir de 1970. De 2000 a 2010, São Gonçalo dos Campos foi o único a apresentar crescimento positivo, com 3.330 habitantes. Feira de Santana é o que apresenta maior decréscimo, na ordem de 3.212; entre 1940 e 2010, perdeu 17.511 pessoas. Sobre a Área de Expansão, houve redução, principalmente a partir da década de 1970, destaque para Ipecaetá, que perdeu entre 2000 e 20103.624 habitantes, e para Serra Preta, que perdeu 3.553. Anguera é o único município que teve decréscimo desde 1970, porém aumentou 538 habitantes de 2000 a 2010.

Quanto à população urbana da RMFS e Área de Expansão, segundo dados do IBGE, observa-se que ambas

Tabela 1. População total, área total, Taxa de Urbanização e densidade demográfica da Região Metropolitana de Feira de Santana e área de expansão, por município, 2010

\begin{tabular}{|c|c|c|c|c|}
\hline Município & População Total & Taxa de Urbanização & Área em $\left(\mathrm{Km}^{2}\right)$ & $\begin{array}{c}\text { Densidade } \\
\text { Demográfica }\left(\mathrm{hab} / \mathrm{km}^{2}\right)\end{array}$ \\
\hline Amélia Rodrigues & 25.190 & 79,23 & 173,484 & 145,2 \\
\hline Conceição da Feira & 20.391 & 64,43 & 162,883 & 125,19 \\
\hline $\begin{array}{l}\text { Conceição do } \\
\text { Jacuípe }\end{array}$ & 30.123 & 78,14 & 117,529 & 256,3 \\
\hline Feira de Santana & 556.642 & 91,73 & 1337,993 & 416,03 \\
\hline $\begin{array}{l}\text { São Gonçalo dos } \\
\text { Campos }\end{array}$ & 33.283 & 49,59 & 300,734 & 110,67 \\
\hline Tanquinho & 8.008 & 71,32 & 219,849 & 36,43 \\
\hline Subtotal & 673.637 & 87,29 & 2312,472 & 291,3 \\
\hline Anguera & 10.242 & 42,24 & 177,044 & 57,85 \\
\hline Candeal & 8.895 & 39,08 & 445,097 & 19,98 \\
\hline Antônio Cardoso & 11.554 & 27,91 & 294,452 & 39,24 \\
\hline Coração de Maria & 22.401 & 41,96 & 348,161 & 64,34 \\
\hline Ipecaetá & 15.331 & 17,20 & 369,889 & 41,45 \\
\hline Riachão do Jacuípe & 33.172 & 59,87 & 1190,196 & 27,87 \\
\hline Santa Bárbara & 5.601 & 45,47 & 345,667 & 13,83 \\
\hline Santanópolis & 8.776 & 19,19 & 230,834 & 38,02 \\
\hline Serra Preta & 15.401 & 44,93 & 536,488 & 28,71 \\
\hline Subtotal & 131.373 & 45,77 & $3.937,828$ & 13,49 \\
\hline
\end{tabular}

Fonte: IBGE, 2010. 
Tabela 2. População urbana e rural da Região Metropolitana de Feira de Santana e área de expansão, por município, 1970-2010

\begin{tabular}{|c|c|c|c|c|c|c|c|c|c|c|}
\hline Setor & & & Urbano & & & & & Rural & & \\
\hline Município & 1970 & 1980 & 1991 & 2000 & 2010 & 1970 & 1980 & 1991 & 2000 & 2010 \\
\hline Amélia Rodrigues & 7.186 & 11.642 & 16.444 & 19.022 & 19.957 & 7.795 & 6.549 & 6.335 & 5.112 & 5.233 \\
\hline Conceição do Jacuípe & 7.101 & 11.079 & 16.174 & 19.466 & 23.539 & 8.062 & 7.660 & 6.731 & 6.728 & 6.584 \\
\hline Feira de Santana & 131.720 & 233.631 & 349.557 & 431.730 & 510.635 & 55.570 & 57.875 & 56.890 & 49.219 & 46.007 \\
\hline Tanquinho & 2.817 & 4.595 & 5.820 & 5.082 & 5.711 & 4.538 & 5.232 & 4.460 & 2.378 & 2.297 \\
\hline Subtotal & 161680 & 276917 & 409393 & 502089 & 591494 & 101.324 & 101.443 & 973.55 & 85.162 & 86.163 \\
\hline Anguera & 1.703 & 2.398 & 2.983 & 3.456 & 4.326 & 5.596 & 5.350 & 4.876 & 5.378 & 5.916 \\
\hline Candeal & 1.338 & 1.824 & 2.541 & 3.417 & 3.476 & 8.380 & 8.948 & 8.187 & 6.704 & 5.419 \\
\hline Riachão do Jacuípe & 5.496 & 10.187 & 14.557 & 15.569 & 19.860 & 44.368 & 52.700 & 23.053 & 16.064 & 13.312 \\
\hline Santa Bárbara & 1.893 & 2.721 & 4.766 & 7.167 & 8.669 & 12.896 & 12.460 & 12.002 & 10.766 & 10.395 \\
\hline Santanópolis & 602 & 731 & 785 & 1.250 & 1.684 & 9.996 & 9.120 & 8.545 & 7.394 & 7.092 \\
\hline Serra Preta & 438 & 476 & 488 & 5.692 & 6.920 & 18.795 & 19.092 & 17.168 & 12.034 & 8.481 \\
\hline Subtotal & 18.830 & 29.356 & 41.277 & 57.117 & 71.443 & 144.206 & 150.893 & 115.683 & 100.252 & 84.639 \\
\hline
\end{tabular}

Fonte: IBGE (1970; 1980; 1991; 2000; 2010)

apresentam crescimento. Contudo, na primeira os municípios que mais se destacam são Conceição do Jacuípe, que apresentou, em 2010, 23.539 habitantes e, principalmente Feira de Santana, ao liderar desde 1940 e teve a população mais que duplicada entre 1960 e 1970, conforme Tabela 2, ao passar de 48.389 para 131.720 habitantes e apresentou, em 2010, 510.635 habitantes. Por sua vez, na Área de Expansão, o destaque é dado a Riachão do Jacuípe, que lidera desde 1940, assim como é o único município a possuir população urbana, para 2010, na ordem de 19.860 habitantes, superior a rural. Isso porque os demais possuem população majoritariamente rural.

Face ao exposto, observa-se que a dinâmica populacionaldos muncipios que compreendem RMFS variou ao longo do tempo, e FNEM (2018) Ihe atribuía, em 14 de maio de 2018, a 27ạ posição dentre as 74 do país.

Sobre a produção econômica, "a RMFS tem papel relevante na base econômica do Estado, concentrando 5,3\% do PIB Estadual, sediando importantes atividades industriais, comerciais e de serviços" (IPEA, 2013, p. 17). No que se refere à oferta de bens e serviços, observa-se que há concentração em Feira de Santana, que se destaca em relação aos demais. No que tange à dinâmica do PIB, observa-se, conforme dados do IBGE, que de 1940 a 2015 a região apresentou maior contribuição do setor terciário, com destaque para Feira de Santana que em 1970 tinha 71,93\%. Quanto à Área de Expansão, a maior contribuição do PIB de 1949 a 1980 resultava do setor primário e a segunda do terciário. A partir de 1999, inverteu-se o padrão de composição do PIB, e passou a ser o terciário em primeiro, exceto em Conceição do Jacuípe.
Quanto ao PIB total, de acordo com Tabela 3, constatou-se que em 2009 e 2015 os municípios que apresentam maiores volumes são Feira de Santana e Conceição do Jacuípe e, na Área de Expansão, destaque para Riachão do Jacuípe. Como pode ser observado no mapa 4, Feira de Santana apresenta superioridade ante a RM e principalmente em relação à Área de Expansão.

$\mathrm{O}$ número de pessoas ocupadas em atividades não agrícolas, notadamente, nos setores secundário, terciário e de serviços, refletem dinâmicas urbano-industriais. Diante disso, ao analisar o percentual ocupado nos setores primário, indústria e terciário, observável na Tabela 4, constatou-se que, para 2000, o maior percentual estava no setor terciário, destaque para Feira de Santana, com 70,49\%; enquanto São Gonçalo dos Campos possuía 45,01\%. Em segundo, o primário, destaque para Tanquinho (37,73\%), enquanto Feira de Santana detinha 8,87\%. A Área de Expansão, em 2000, possuía o setor primário com maior percentual, destaque para Santanópolis com 80,50\%; Riachão do Jacuípe tinha o menor valor, $36,75 \%$. Os demais municípios possuíam acima de $50 \%$ de ocupação no setor primário. Em segundo, terciário, destaque para Riachão do Jacuípe, com 47,67\%; Santanópolis tinha 15,32\%.

Para 2010, na RMFS, o setor terciário, apesar de ter maior percentual de pessoas ocupadas, diminuiu, juntamente com o setor primário, ao passo que a indústria e a construção aumentaram. Para o terciário, Feira de Santana continuou a apresentar o maior percentual, com 71,05\%. Em segundo lugar, tem-se o primário, destaque para Conceição da Feira, 

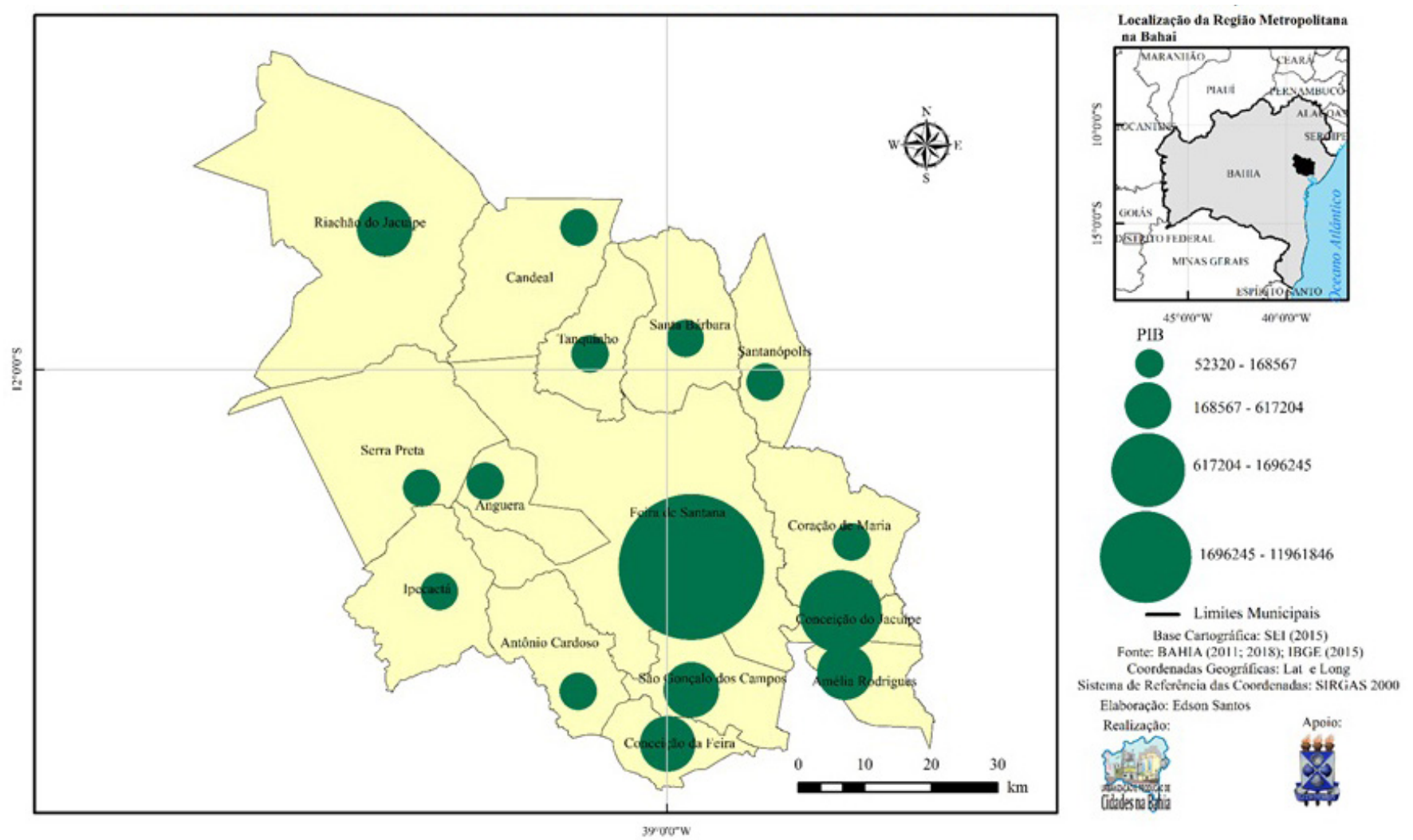

Mapa 4- PIB da Região Metropolitana de Feira de Santana e Área de Expansão, 2015

com 36,35\%, enquanto que Feira de Santana apresentou 7,28\%. Em relação à Área de Expansão, ao comparar 2002 e 2010, constatou-se que o setor primário, apesar de diminuir os percentuais, continuou a liderar, ao passo que os demais

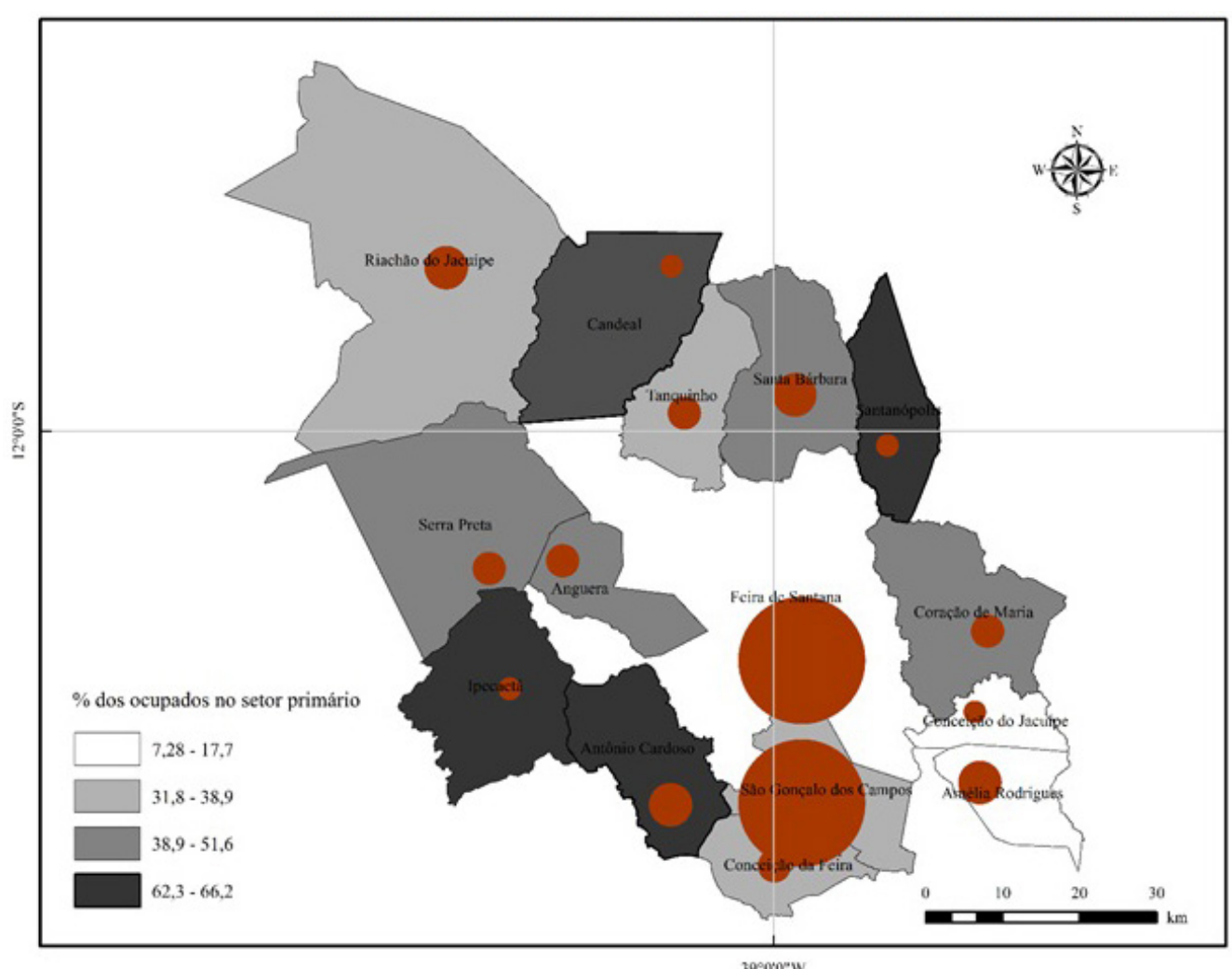

cresceram. Tem-se Ipecaetá, que apresentou maior percentual 66,21\%; enquanto Riachão do Jacuípe possuiu 33,3\%. Em segundo, encontra-se o terciário, realce para Riachão do Jacuípe, 51,65\%; Ipecaetá apresentou 25,0\%.

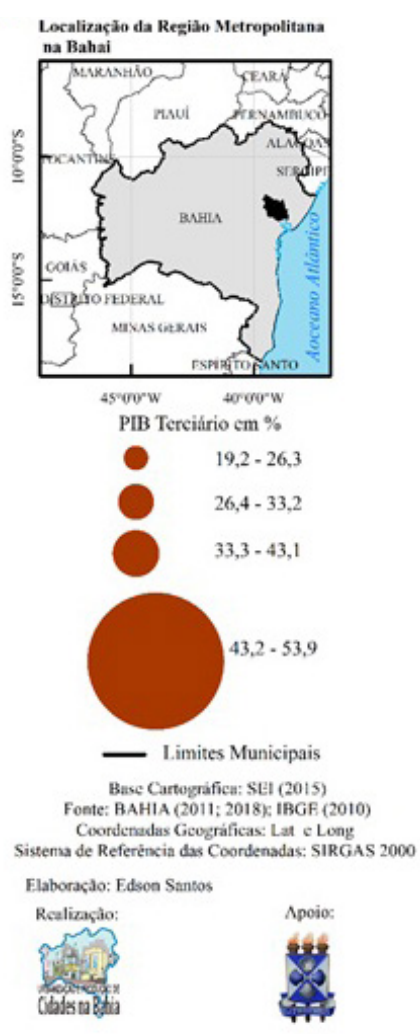

Mapa 5- Percentual da Ocupação no Setor Primário, 2010, do PIB Terciário, 2015, da Região Metropolitana de Feira de Santana e Área de Expansão 
Tabela 3. Produto Interno Bruto (PIB) total e percentuais do PIBde impostos, agricultura, indústria, terciário, serviços públicos, por município - Região Metropolitana de Feira de Santana e área de expansão - 2015, 2009

\begin{tabular}{|c|c|c|c|c|c|c|}
\hline Município & \multicolumn{6}{|c|}{2015} \\
\hline Amélia Rodrigues & 264509 & 7,73 & 10,25 & 8,95 & 43,1 & 29,97 \\
\hline Conceição da Feira & 248511 & 10,13 & 10,46 & 22,75 & 30,34 & 26,31 \\
\hline Conceição do Jacuípe & 1696245 & 27,49 & 1,61 & 45,91 & 19,21 & 5,79 \\
\hline Tanquinho & 52806 & 3,92 & 11,13 & 6,57 & 33,19 & 45,19 \\
\hline Anguera & 60984 & 6,09 & 6,38 & 4,65 & 32,33 & 50,55 \\
\hline Candeal & 52320 & 2,82 & 17,31 & 3,81 & 26,27 & 49,8 \\
\hline Antônio Cardoso & 97966 & 9,27 & 8,77 & 5,19 & 38,23 & 38,54 \\
\hline Riachão do Jacuípe & 280234 & 4,95 & 10,14 & 8,56 & 40,19 & 36,16 \\
\hline Santa Bárbara & 150647 & 7,07 & 7,06 & 9,01 & 39,66 & 37,2 \\
\hline Santanópolis & 56214 & 2,58 & 10,19 & 5,76 & 23,63 & 57,84 \\
\hline Serra Preta & 94266 & 3,57 & 13,54 & 6,6 & 29,06 & 47,23 \\
\hline \multirow{2}{*}{ Município } & \multicolumn{6}{|c|}{2009} \\
\hline & Total & Impostos & Agricultura & Indústria & Terciário & Serviços Públicos \\
\hline Amélia Rodrigues & 153448 & 9,2 & 11,02 & 16,65 & 37,76 & 25,38 \\
\hline Conceição da Feira & 92851 & 11,31 & 18,35 & 10,11 & 24,82 & 35,41 \\
\hline Candeal & 24682 & 3,14 & 9,73 & 4,1 & 26,59 & 56,45 \\
\hline Antônio Cardoso & 65694 & 10,6 & 7,27 & 4,69 & 45,33 & 32,12 \\
\hline Coração de Maria & 113462 & 24,09 & 14,32 & 8,26 & 20,3 & 33,03 \\
\hline Ipecaetá & 44516 & 2,56 & 12,48 & 3,64 & 19,37 & 61,96 \\
\hline Riachão do Jacuípe & 125179 & 5,42 & 7,7 & 7,53 & 38,49 & 40,86 \\
\hline Santa Bárbara & 92091 & 9,22 & 10,18 & 8,8 & 37,85 & 33,95 \\
\hline Santanópolis & 26827 & 2,23 & 20,11 & 3,67 & 18,56 & 55,44 \\
\hline Serra Preta & 48892 & 4,04 & 10,52 & 7,64 & 25,39 & 52,41 \\
\hline
\end{tabular}

Fonte: IBGE $(2015 ; 2009)$

Ao relacionar o PIB com as pessoas ocupadas, observa-se que na RMFS os municípios que mais apresentam características econômicas com tendência metropolitana, ao verificar os percentuais do PIB para o terciário e a indústria, são Feira de Santana, Conceição do Jacuípe e São Gonçalo dos Campos. Na Área de Expansão, o peso maior do PIB resulta do terciário. Contudo, ao relacionar com a ocupação, observa-se que os maiores percentuais estavam no setor primário (ver Mapa 5).
Face ao exposto, ao se comparar a RMFS com sua Área de Expansão Metropolitana, observa-se que a primeira, mesmo que agregue apenas seis municípios, com exceção do tamanho territorial, é superior no que se refere à população, densidade demográfica e PIB, entre outros.

Observa-se que o peso do terciário apresentado por boa parte dos municípios da RMFS e de sua Área de Expansão é fortemente influenciado pelos serviços públicos, ligados ao funcionalismo público, o que mostra a dependência em relação 
Tabela 4. Percentual da ocupação no setor primário, indústria, construção e terciário, por município - Região Metropolitana de Feira de Santana e área de expansão - 2000, 2010

\begin{tabular}{|c|c|c|c|c|c|c|c|c|}
\hline Município & \multicolumn{4}{|c|}{2000} & \multicolumn{4}{|c|}{2010} \\
\hline Amélia Rodrigues & 15,93 & 10,99 & 10,24 & 62,83 & 19,1 & 12,48 & 14,51 & 53,91 \\
\hline Conceição da Feira & 27,00 & 8,62 & 9,57 & 54,80 & 36,35 & 4,93 & 11,35 & 47,37 \\
\hline Conceição do Jacuípe & 26,66 & 8,94 & 7,92 & 56,49 & 17,77 & 19,46 & 10,35 & 52,42 \\
\hline São Gonçalo dos Campos & 33,08 & 12,92 & 9,00 & 45,01 & 31,85 & 14,1 & 10,9 & 43,15 \\
\hline Tanquinho & 37,73 & 6,63 & 3,42 & 52,22 & 32,74 & 6,58 & 6,36 & 54,32 \\
\hline Anguera & 62,78 & 1,88 & 6,23 & 29,10 & 38,92 & 4,72 & 10,67 & 45,69 \\
\hline Candeal & 54,95 & 2,89 & 4,57 & 37,59 & 62,55 & 2,94 & 3,94 & 30,57 \\
\hline Riachão do Jacuípe & 36,75 & 9,92 & 5,66 & 47,67 & 33,3 & 8,27 & 6,78 & 51,65 \\
\hline Santa Bárbara & 60,31 & 2,49 & 4,09 & 33,11 & 49,44 & 5,14 & 6,25 & 39,16 \\
\hline Santanópolis & 80,50 & 1,02 & 3,17 & 15,32 & 62,3 & 2,74 & 6,15 & 28,82 \\
\hline Serra Preta & 59,83 & 3,30 & 4,59 & 32,29 & 49,85 & 4,76 & 7,01 & 38,39 \\
\hline
\end{tabular}

Fonte: IBGE $(2000 ; 2010)$

aos recursos do Estado. Isso porque o maior volume do terciário (comércio, entre outros serviços e órgãos públicos), como dito, encontra-se em Feira de Santana e, logo, nos municípios pequenos é incipiente. Algo que indica uma dinâmica típica de municípios rurais, já que grande parte das pessoas estão ocupadas no setor primário e não os qualifica como de caráter urbano-metropolitano.

\section{CONSIDERAÇÕES FINAIS}

As RMs são recortes urbanos instituídos por meio de lei complementar, em função do crescimento das cidades para além de seus limites administrativos, dentre outras várias razões. Dinâmicas que causam problemas urbanos, dada a demanda por serviços de transportes, saúde, segurança, habitação e saneamento, devido ao fluxo de pessoas que moram e transitam nesses espaços. Por isso, a necessidade que nessas regiões sejam realizados planejamento em conjunto e gestão compartilhada para a realização de funções públicas de interesses comuns.

Pautado nessa prerrogativa, essas têm se proliferado no Brasil, principalmente a partir da constituição de 1988 , quando foi transferido aos estados o direito de instituírem aglomerados urbanos, segundo seus próprios critérios. Tal proliferação resulta de uma prática que remonta ao período da Ditadura Militar, cuja política destinava benefícios para os municípios pertencentes a essas regiões. No contexto atual, os benefícios continuam a serem justificados, em virtude da importância socioeconômica e dos problemas que apresentam.
A solução para a redução das desigualdades socioespaciais e o fortalecimento socioeconômico metropolitano são justificados por discursos políticos que predizem benefícios para os municípios e a população que integram a RM, caso o projeto de lei seja aprovado, tal como ocorreu com a RMFS. Dada a importância demográfica e econômica, sobretudo em relação à oferta de bens e serviços, concentrados em Feira de Santana, institucionalizada enquanto "metrópole", como forma de alavancar o desenvolvimento sustentável e equilibrado dos municípios limítrofes a ela, ao menos nos discursos.

Todavia, ao analisar as características da RMFS e Área de Expansão, ainda sem regulamentação, concluise que regionalizações colocam acertadamente Feira de Santana enquanto centralidade, dada em função de concentrar serviços e equipamentos, públicos e privados. Exceto Feira de Santana, Conceição do Jacuípe e Riachão do Jacuípe, os demais municípios dessa região e Área de Expansão não possuem caráter metropolitano, pois, dentre outros elementos não-metropolitanos, apresentam alto percentual de pessoas que trabalham no setor primário, baixa urbanização, PIB do setor terciário fortemente influenciado pelo setor de serviços públicos, que, por sua vez, tem incipiente número de pessoas ocupadas no setor terciário que seja desvinculado desse setor. Algo que indica a dependência econômica de transferência de recursos do Estado e munícipio, dinâmica mais típica de municípios demográfica e economicamente rurais, o que não justifica inclui-los em uma RM. 


\section{REFERÊNCIAS}

ASSEMBLÉIA DO ESTADO DA BAHIA (ALBA). Deputados aprovam criação da Região Metropolitana de Feira, Assembleia do Estado da Bahia, Salvador, 17 jun. 2011. Disponível em: <http://www.alba.ba.gov.br/midia-center/ noticia/10557>. Acesso: 01mai 2016.

BAHIA. Atividade legislativa, no Proposição: MSG/4.677/ 2011a. Salvador, 14 de jun. 2011. Disponível em:<http:// www.alba.ba.gov.br/atividade-legislativa/proposicao/ MSG/4.677/2011>. Acesso: 09 dez 2018.

Lei Complementar № 35 de 06 de julho de 2011. Institui a Região Metropolitana de Feira de Santana, e dá outras providências. Diário Oficial do Estado da Bahia, Salvador: EGBA, 06 de jul. de 2011a.

. Projeto de lei complementar no 109/2011b. Institui o município de Santo Estevão como parte integrante da Região Metropolitana de Feira de Santana e dá outras providências. Disponível em: <http://www.al.ba.gov.br/atividade- legislativa/ proposicao/PLC/109/2011>Acesso: 01 dez 2018.

Projeto de lei complementar $n^{\circ}$ 132/2018a. Disponível em: <www.al.ba.gov.br/docs/Proposicoes2018/ PLC_132_2018_1.rtf.> Acesso: 11 out 2018.

BRASIL. Decreto no 4.366, de 9 de setembro de 2002. Regulamenta a Lei Complementar no 113, de 19 de setembro de 2001, que autoriza o Poder Executivo a criar a Região Administrativa Integrada de Desenvolvimento do Pólo Petrolina/PE e Juazeiro/BA e instituir o Programa Especial de Desenvolvimento do Pólo Petrolina/PE e Juazeiro/BA, e dá outras providências. Disponível em: <http://www.planalto.gov. br/ccivil_03/decreto/2002/D4366.htm>. Acesso: 10 dez 2018.

. Lei Complementar no 14, de 8 de junho de 1973. Estabelece as regiões metropolitanas de São Paulo, Belo Horizonte, Porto Alegre, Recife, Salvador, Curitiba, Belém e Fortaleza. Disponível em: <https://www.planalto.gov.br/ ccivil_03/leis/lcp/lcp14.htm> Acesso 08 mar 2016.

. Lei Complementar no 20, de 1o de julho de 1974. Dispõe sobre a criação de Estados e Territórios. Disponível em: <http://www.planalto.gov.br/ccivil_03/LEIS/LCP/Lcp20. htm> Acesso: nov 2018.

. Lei n.o 5.727, de 4 de novembro de 1911. Dispõe sobre o Primeiro Plano Nacional de Desenvolvimento (PND), Para o período de 1972 a 1974. Disponível em: <http://www. biblioteca.presidencia.gov.br/publicacoes-oficiais/catalogo/ medici/i-pnd-72_74> Acesso 06 dez 2018.

II Plano Nacional de Desenvolvimento.Dispõe sobre o PrimeiroPlano Nacional de Desenvolvimento (PND), Para o período de 1975a 1979. Disponível em: <file:///C:/ Users/User/Downloads/II\%20PND\%2075_79.pdf>. Acesso: 06 dez 2018.
III Plano Nacional de Desenvolvimento. Dispõe sobre o Primeiro Piano Nacional de Desenvolvimento (PND), Para o período de 1980 a 1985. Disponível em: <file://C:/ Users/User/Downloads/III\%20Plano\%20Nacional\%20de\%20 Desenvolvimento\%201980-1985_PDF_OCR.pdf.>Acesso: 06 dez 2018.

Lei complementar no 14, de 8 de junho de 1973.

Constituição da República Federativa do Brasil de 1988. Disponível em: http://www.planalto.gov.br/ccivil_03/Cons tituicao/Constituicao.htm> Acesso em: Acesso em: 8 mar 2016.

Lei 11.530, 24 de outubro de 2007.Institui o Programa Nacional de Segurança Pública com Cidadania PRONASCI e dá outras providências. Disponível em:

<http://www.planalto.gov.br/> Acesso: 09 dez 2019a.

Ministério do Planejamento. Programa de Aceleração do Crescimento - PAC. 2018. Disponível em: <http://www.pac.gov.br/sobre-o-pac>Acesso: 06 dez 2018.

Lei complementar no 113, de 19 de Setembro de 2001. Autoriza o Poder Executivo a criar a Região Administrativa Integrada de Desenvolvimento do Pólo Petrolina/PE e Juazeiro/BA e instituir o Programa Especial de Desenvolvimento do Pólo Petrolina/PE e Juazeiro/BA. Disponível em: <http://www.planalto.gov.br/ccivil_03/leis/ Icp/Lcp113.htm>Acesso: 06 dez 2018.

Lei no 13.089, de 12 de janeiro de 2015. Institui o Estatuto da Metrópole, altera a Lei no 10.257, de 10 de julho de 2001, e dá outras providências. Disponível em:

<http://www.planalto.gov.br/ccivil_03/_Ato20152018/2015/Lei/L13089.htm>Acesso: 06 dez 2018.

FEIRA DE SANTANA. Projeto de Lei Complementar no 003, de 03 de abril de 2018a. Dispõe sobre o plano diretor de desenvolvimento urbano e territorial do município de Feira de Santana - PDDU 2018 e dá outras providências. Disponível em: <http://feiradesantana.ba.leg.br/wp-content/uploads/ 2018/08/PIco20180003-PDDU.pdf.>. Acesso: 06 dez 2018.

Desenvolvimento da Região Metropolitana de Feira de Santana, e dá outras providências. Disponível em:<https://leismunicipais.com.br/a2/ba/f/feira-desantana/resolucao/2018/52/516/resolucao-n-516-2018cria-a-frente-parlamentar-mista-de-desenvolvimento-daregiao-metropolitana-de-feira-de-santana-e-da-outrasprovidencias>. Acesso: 06 dez 2018.

FIRKOWSKI, O. L. C. de F.; MOURA, R. Regiões metropolitanas e metrópoles: reflexões acerca das espacialidades e institucionalidades no Sul do Brasil. Revista RA'E GA: O espaço geográfico em análise. Curitiba: Dep. de Geografia/UFPR, v. 5, n. 5, 2001, p. 27-46.

FIRKOWSKI, Olga Lúcia Castreghini de Freitas. Região metropolitana no Brasil: assim é se Ihe parece... I SIMPÓSIO 
DE ESTUDOS URBANOS, Desenvolvimento Regional e dinâmica ambiental Universidade Estadual do Paraná. Anais [...]. Campus de Campo Mourão, 2011.

FNEM, Fórum Nacional de Entidades Metropolitana. Disponível em: https://www.google.com/search?q=Entidad es+nacional+metropolitanas\&oq=Entidades+nacional+metr opolitanas+\&ie=UTF-8. Acesso: 06 dez 2018.

FREITAS, Nacelice Barbosa. 0 descoroamento da princesa do sertão: de "chão" a território, o "vazio" no processo de valorização do espaço. 2014. 416 f. Tese (Doutorado) Universidade Federal de Sergipe, São Cristóvão, 2014.

INSTITUTO BRASILEIRO DE GEOGRAFIA E ESTATÍSTICA (IBGE). Divisão regional do Brasil em regiões geográficas imediatas e regiões geográficas intermediárias: 2017/IBGE, Coordenação de Geografia. - Rio de Janeiro: IBGE, 2017. 82p

Regiões de influência das cidades 2007. Rio de Janeiro 2008. Disponível em: <http://www.mma.gov.br/ estruturas/PZEE/_arquivos/regic_28.pdf>Acesso: 06 dez 2018.

BGE. Censo Demográfico: população e habitação, 1940. Parte XII, tomo I, série regional. Rio de Janeiro: IBGE, 1950.

Censo Demográfico: Estado da Bahia, 1950. V. XX, tomo I. Rio de Janeiro: IBGE, 1955.

Sinopse Preliminar do Censo Demográfico: Brasil. 1960. Rio de Janeiro: IBGE, 1960.

. Censo Demográfico Bahia: recenseamento geral, 1970, v. 1, tomo XIII. Rio de Janeiro: IBGE, 1973.

Censo Demográfico 1980: dados distritais-Bahia, v. 1, tomo 3, n. 13. Rio de Janeiro: IBGE, 1983,

. Censo Demográfico 1991: resultados do universo relativos às características da população e dos domicílios, n.17-Bahia Rio de Janeiro: IBGE, 1991.

Sidra: Bando de dados sobre Censo Demográfico. Rio de Janeiro: IBGE, 2000. Disponível em: http://www.sidra. ibge.gov.br. Acesso: 06 dez 2018.

Sidra: Bando de dados sobre Produção Municipal. Rio de Janeiro: IBGE. Disponível em: http://www.sidra.ibge. gov.br. Acesso: 06 dez 2018.

. Censo Demográfico, Rio de Janeiro: IBGE, 2010. Disponível em: http://www.ibge.gov.br/censo2010/. Acesso: 06 dez 2018.

Sidra: Banco de dados sobre Produto Interno Bruto 1999 e 2014. Disponível em:http://www.sidra.ibge. gov.br. Acesso: 06 dez 2018.

FREITAS, Ruskin. Regiões Metropolitanas: uma abordagem conceitual. Revista Humanae, Santo Amaro/PE, v.1, n.3, 2009, p. 44-53.
IPEA. Caracterização e quadros de análise comparativa da governança metropolitana no Brasil: arranjos Institucionais de Gestão Metropolitana. 15 de abril de 2013.

GALVÃO, M. V. et al. Áreas de pesquisa para determinação de áreas metropolitanas. Revista brasileira de geografia, Rio de Janeiro, IBGE, ano 31, n. 4, p. 53-127, out./dez. 1969.

PEREIRA, Luiz Andrei Gonçalves. Redes e fluxos em geografia: uma abordagem teórica. Revista Tocantinense de Geografia, Araguaína (TO), v. 4, n.5, jan-jul. de 2015, p. 1-18.

MAGALHÃES, José Luiz Quadros de. Regiões Metropolitanas. Conteúdo Jurídico, Brasília-DF: 03 dez. 2008. Disponível em:<http://www.conteudojuridico.com. br/?artigos\&ver=2.21967\&seo=1> Acesso: $06 \mathrm{dez} 2018$.

MOREIRA JR, Orlando. Região metropolitana e desenvolvimento: embates, desafios e incertezas na RM de Campinas-SP. In: VI SEMINÁRIO INTERNACIONAL SOBRE DESENVOLVIMENTO REGIONAL. CRISES DO CAPITALISMO, ESTADO E DESENVOLVIMENTO REGIONAL. Anais [...]. Santa Cruz do Sul, 4 a 6 de set, 2013.

MATOS, Josadac Figueira de. Aspectos políticos e institucionais da administração metropolitana no Brasil: o caso de Belo Horizonte. 1983. 206p. Dissertação (Mestrado em Administração) - Escola Brasileira de Administração Pública e de Empresas, Fundação Getúlio Vargas - FGV, Rio de Janeiro, 1982.

OBSERVATÓRIO DAS METRÓPOLES. Níveis de integração dos municípios brasileiros em RMs, RIDES e AUs à dinâmica da metropolização. Rio de Janeiro, Dezembro/2012. 108p. Disponível em: <http://observatoriodasmetropoles.net/ download/relatorio_integracao.pdf>Acesso: 06 dez 2018.

ROBIRA, Rosa Tello. Áreas Metropolitanas: espaços Colonizados. In: CARLOS, Ana Fani Alessandri; CARRERAS, Carles (Org.). Urbanização e Mundialização: Estudos Sobre a Metrópole. São Paulo: Contexto, 2005, p. 9-20.

SILVA, Cleonice Moreira da. A princesinha do sertão agora é metrópole?! Uma análise do processo de "metropolização" de Feira de Santana-Ba. 2014. 225 f. Dissertação. (Mestrado em Geografia) - Instituto de Geociências, Universidade Federal da Bahia. Salvador, 2014.

SOMEKH, N. Regiões metropolitanas no Brasil: desenvolvimento e território. In: SEMINÁRIO NACIONAL GOVERNANÇA URBANA E DESENVOLVIMENTO METRO-POLITANO, Natal. Anais [...] Rio de Janeiro: observatório das Metrópoles, 2010

TRINDADE, Andrea. Aeroporto de Feira de Santana iniciará voos diários para São Paulo em dezembro. Acorda Cidade, Feira de Santana, 03 ago. 2018. Disponível em: <https:// www.acordacidade.com.br/noticias/197779/aeroporto-defeira-de-santana-iniciara-voos-diarios-para-sao-paulo-emdezembro.html?mobile=true $>$. Acesso em: 19 de dez. de 2018. 